How to cite this article:

Abbas, M., Ali, A., \& Khalid, M. A. (2019). Leadership style and employees' performance in pakistan: the mediating role of organisational commitment. Malaysian Management Journal, Vol. 23(December), 115-134.

\title{
LEADERSHIP STYLE AND EMPLOYEES' PERFORMANCE IN PAKISTAN: THE MEDIATING ROLE OF ORGANISATIONAL COMMITMENT
}

\author{
MUHAMMAD ABBAS \\ ASIF ALI* \\ MUHAMMAD AHSAN KHALID \\ University of Management and Technology Lahore, Pakistan \\ *Corresponding author: rajaasif92@gmail.com
}

\begin{abstract}
The paper investigates the critical role of organisational commitment between leadership style and employees' performance. Generally, the relationship between leadership style and the organisational performance has been discussed widely but ignoring the employees' performance. It has been accepted that the organisational commitment leads to higher employee performance but the existing literature has not focused much on this view. A conceptual model has been developed which links the constructs together. The model reveals the missing link of organisational commitment between leadership style and employees' performance. The sample of 242 was collected from the managers and employees of manufacturing and service organisations. The finding confirmed that organisational commitment acted as a mediator between the leadership style and employees' performance.
\end{abstract}

Keywords: Leadership styles, employee performance, transformational leadership, organisational commitment. 


\section{Introduction}

The basic concept of leadership style changes from person to person based upon the situation, or other factors. The word leadership has a wide range of meanings in human life external factors like enterprises, education, training, and daily social work (Choi, Kim, Ullah \& Kang, 2016). The workforce nowadays is more educated and aware of better values which they expect from their leadership and at the same time, the organisation tries its best to consume their competencies for more output (Dong, Bartol, Zhang \& Li, 2017). As the commitment level of employees' increases, the tendency to leave decreases and their output increases as the commitment brings out their best performance (Aarabi, Subramaniam \& Akeel, 2013).

An effective leader acts as a guide for employees, steers them in the right direction which results in having employees with high job satisfaction and they exert more effort in achievement of tasks, bringing success to his / her organisation and thus is more committed towards the organisation (Shah, Majid, Samo \& Memon, 2016). If leaders do not invest themselves into the vision and mission of the organisation then insecurity, low confidence and lack of commitment will ensue amongst the employees (Khan, 2016). Organisational commitment spawns new ideas with effective output in the firm (Masa'deh, Obeidat \& Tarhini, 2016). Leadership style of the management is not immune to the cultural effects; it varies depending upon the overall outlook of local culture and norms (Grant, 2012). Theoretically, leadership may be defined as, "[a] process of dealings between leaders and assistants where a leader tries to sway the behaviour of his / her subordinates to achieve company goals" (Lo, Ramayah, Min \& Songan, 2010; page number needed here).

Early research has explored that a leadership style which enhances the commitment level of an employee is a key to an organisation to be successful in implementing the business strategies, achieving targets, gaining competitive edge and optimising human capital (Dvir, Eden, Avolio \& Shamir, 2002; Erkutlu, 2008). Contemporary researchers described that any organisation's success not only depend on the human work but also on their efficiency and effectiveness (Nijhof, de Jong, \& Beukhof, 1998). Nijhof et al. (1998) related the success of organisation not only to the human capital and their competencies but also to the organisational efficiency that is increased through commitment. Leadership style is a not only the key to make the workplace efficient but it is also helpful in improving individuals' progress in making the organisation more proficient. Glantz's (2002) emphasized 
that it must be an important area of interest of the higher management for adoption of suitable leadership style. Effective utilization of organizational resources by individuals is directly connected to choice of leadership style by the managers. The objective of this study is to attempt to gauge the relationship of leadership style on enterprises efficiency. This will further serve as a contribution towards quantitative studies in which the relationship of employee performance and leadership style will be tested.

The corporate business environment throughout the world including Pakistan is facing immense market competition. In order to survive or compete in this globalization era, the organisations in Pakistan should have adaptive capability for incremental or radical change in such conditions. The study will help leaders to understand how crucial it is for them to attract, develop and retain effective and adaptive workforce using transformational leadership style to enhance employee's performance (Vigoda-Gadot, 2007). The study will also add valuable contributions in the literature of human resource management by linking effective leadership style with employee's performance. The paper will provide the theoretical model that will depict the path on how leadership directly and indirectly leads towards the employee's performance.

Although majority of the corporate leaders now view leadership as vital for the long term success of their business, but most of them are still following the traditional approaches of leadership whose benefits seldom exceed their costs (Schaubroeck, Lam \& Cha, 2007). Different studies have revealed the relationship of leadership style and organisational commitment with emotional effect as a moderating variable (Alkahtani, 2015). On the other hand, the relationship of leadership styles and organisational commitment with the employees' value as the mediator had also been tested in earlier studies (Sabir, Sohail \& Khan, 2011). But, these studies have not elaborated the mediating role of organisational commitment to enhance the employees' performance. In addition, these studies have described the relation of organisation output, leadership styles and commitment or performance while not connecting them with the employee performance.

The study focuses on the relation between the employee output (performance) and the leadership style, employee performance, and organisational commitment. In addition, for the empirical analysis of their relationship, the paper will also attempt to provide logical explanation on how leadership enhances organisational commitment and how organisational commitment, in turn, enhances employee performance. The study will tend to answer the following research questions: 
1. Do leadership styles increase the organisational commitment?

2. Do leadership styles enhance the employee's performance?

3. Does organisational commitment mediate the relation between leadership and employee performance?

\section{Literature Review}

The literature review section has been divided into five parts; 1) on leadership style, organisational commitment and employee performance to have an in-depth understanding of these variables; 2) on the leadership styles and employee commitment for an understanding of what leadership is and how it enhances employee's commitment; 3 ) on the employee commitment and employee performance to understand what employee performance actually means and how employees' commitment leads to the enhancement of their performance; 4) On the leadership style and employee performance for an understanding of how leadership style and employee performance are related to each other, and 5) on the employee commitment as a mediator between leadership style and employee performance to indicate that employee's commitment plays an intermediary role between the leadership style and employee performance.

\section{Leadership is Essentially a Moral Act}

Trust is the hallmark of leader-subordinate relationship in organisations. The individuals at workplace are the sheet anchors of creating this trust factor. If this leader-subordinate relationship is positive, it means there is a strong bondage of trust, and it will result in higher organisational outcome (Babalola, 2016). The trust factor creates a strong relationship amongst the leaders and their employees (Dvir et al., 2002). By developing trust, leaders can look forward to desired results from their employees. This relationship will increase as leaders will sense themselves a part of the organisation which provides equal opportunities to all (Schaubroeck et al., 2007). In addition, this relationship becomes even more important at the team level as the leader shares with his team members the knowledge about project/goals (McCleskey, 2014) which not only results in efficacy but also efficiency. Moreover, it leads to the best possible outcome of any assigned tasks (Lee, Gillespie, Mann, \& Wearing, 2010).

Transformational leadership that "emphasises emotions and values, draws upon the symbolic behaviour and the role of the leader in making the events meaningful for followers." (Yukl \& Yukl, 2002). Burns (1978) viewed "transformational leadership as a process that elevates followers from their 
everyday selves to their better selves" (p. 20). The success or failure of any organisation is mostly dependent on leadership. In previous studies, the relationships between leadership style and employee performance have been broadly discussed (Bass \& Stogdill, 1990; Manz \& Sims, 1991; Morden, 1997; Sarros \& Woodman, 1993). Empowerment and clear vision which are embedded in the transformational leadership are normally taken as the key features for commitment (Sergiovanni \& Corbally, 1984; Smith \& Peterson, 1988). As the organisations are being run by the top management, the role of employees is not significant but it is the primary task of the top management to create a feeling amongst employees that they are the key part of the organisation (Ghasabeh, Soosay \& Reaiche, 2015). This type of leadership style is liked by the employees as they feel sense of empowerment.

Contrary to this, the employees feel uncomfortable if their ideas and suggestions are not taken seriously thus leading to de-motivation. They like a system where their ideas are given proper weightage. Such system not only enhances their motivation factor but also produces positive results for the organisation (Jamaludin, Rahman, Makhbul \& Idris, 2011). This exhibits the leadership which is considered a two way process. This process means that a leader affects his followers and followers affect the leader (Ardichvili $\&$ Manderscheid, 2008). Earlier researches have revealed that leaders have strong and lasting influence on their subordinates as they are not only caretakers but also the role models (Germain, 2012).

Hence, transformational leadership is an art of sensing the need for change, creation of new visions, and activating dedication to catch up these visions. As future foresightedness is a key component of transformational leadership (Den Hartog \& Verburg, 1997), such leadership not only transforms individuals but also the organisations (Bass, 1985; Pradhan \& Pradhan, 2015). Meyer and Allen defined organisational commitment as "the emotional attachment of an employee to organization" (Meyer \& Allen, 1991, page number is missing?). Kanter (1968) defined commitment as "the willingness of social actors to give energy and loyalty to the organisation" (Kanter, 1968, page number missing?). Another commitment involves the "willingness of employees to exert higher efforts on behalf of the organization, a strong desire to stay in the organization, and accept major goals and values of the organization" (Porter \& Lawler, 1968, page number missing?)

Organisational commitment is based on just environment, organisational justice, equity in compensation and benefit. These factors help in the enhancement of employee engagement which results in the organisational commitment. Organisational commitment has remained a central focus of attention for researchers in previous decades due to its potential benefits for 
organisations in particular and individuals in general (Somers \& Birnbaum, 1998). Organisational survival and efficacy is heavily based on this key factor (Buchanan, 1974). Earlier studies have revealed a positive relationship between organisational commitment and employee behaviours which leads to organisational effectiveness (Randall, Fedor \& Longenecker, 1990). Research has also explored that organisational commitment has positive relation with employees and organisation with regard to the adaption of dynamic changes (Brown \& Sargeant, 2007). The researchers advocates that organisational commitment promotes OCB which is a key to organisational success, effective team building, and employee empowerment (Dessler, 1999). Organisational commitment helps in employee retention, higher productivity, superior work quality, and personal sacrifice on behalf of the organisation ( $\mathrm{Ng}, 2015)$. Commitment is also one the most important factors for the organisational endurance and development (Kofman \& Senge, 1993).

The employee performance is defined as "all the behaviors employees engage in while at work" (Khan, 2016, page number?). Further, it is defined as the "employee performance as the behavior executed in line with the set objectives of the organization" (Chaudhary \& Sharma, 2012, page number?). The key features related to employee performance are perceived as the organisational support, job security, motivation level, job satisfaction, job engagement, task performance and core self-evaluation. Kahn's (1990) concept about employees having to to put in physical, cognitive, and emotional energies collectively into the role as the performers, has received a large degree of criticism (Newman \& Harrison, 2008). In order to increase the employees' performance, managers have to face numerous challenges, that is, managing motivational factors of employees through taking care of their personal and career needs (Alonso \& Lewis, 2001; Wright, Moynihan, \& Pandey, 2012).

Employee performance and organisational productivity are correlated to achieve organisational goals. Besides employee performance, organisational productivity is also hampered by some other factors. Organisations can be successful in attaining their goals if they understand the nexus between employee's performance and organisational productivity (Akerlof \& Kranton, 2010). Early empirical research has revealed that job security as a motivational factor has a positive relationship with employee performance (Buelens \& Van den Broeck, 2007). Job security significantly affects the performance of workers, and similarly low level of job security de-motivates employees (Miller \& Cohen, 2001). Employees perform their job more effectively in conducive environments. Equally, respect factor among peers and management is not only helpful in creating a healthy work environment but also enhances employee's performance (Halbesleben \& Bowler, 2007). 
Both behavioral theory and path goal theory support this study but we focus on the path goal theory which supports our theoretical model. Path goal theory describes the leader's style or behaviour that creates a fit between the employee and work environment to achieve the desired goals (House $\&$ Mitchell, 1975). The main goal is to increase the employees' motivation, empowerment and satisfaction so they become more productive members of the organisation.

\section{Leadership Styles and Organisational Commitment}

On the study of firms in Singapore, Lee (2004) found a significant relationship between the transformational leadership and organisational commitment, whereas no significant relationship was found between transactional leadership and organisational commitment. Other researchers also found that transformational leadership positively moderates affective commitment (Hayward, Goss \& Tolmay, 2004). A low relation was also found amongst transformational leadership and normative and continuance commitment. However, no relation was found between the transactional leadership and all forms of commitment. Transformational leadership motivates employees which, in turn, enhances trust, commitment and team efficiency (Arnold, Barling \& Kevin Kelloway, 2001). Contemporary research has emphasised that transformational leadership also positively affects follower perceptions, which results into a high level of trust among leaders and followers. Moreover, the level of commitment to the leader, level of performance among employees, and the overall level of organisational commitment also increases (DuBrin, 1998). Following the above arguments, we propose the hypothesis.

$\mathrm{H}_{1}$ : Leadership style has a positive relationship with the organisational commitment.

\section{Organisational Commitment and Employee Performance}

The current research has revealed that the employee performance and organisational commitment are the most important factors for the top management (Farndale, Van Ruiten, Kelliher \& HopenHailey, 2011). Dedicated and devoted employees of an organisation exhibit positive behaviours and the employee turnover rate in such organisations is very low (Khan, Khan \& Khan, 2011; Robbins \& Coulter, 2007). Performance is related to the specific skills of employees applied in specific situations (Prasetya \& Kato, 2011). Dharma (1991) in his research emphasised that performance is something that is prepared, or products prepared by skilled employees. Meanwhile, Kitchard and Strawser (2001) and Clarke (2006) 
proposed that commitment is positively related to employee performance in their research on commitment and network performance in the UK-based health care units. Hence, we conclude that organisational commitment has a positive relation with the employees' performance. Following the above arguments, we propose the hypothesis.

$\mathrm{H}_{2}$ : Organization commitment has a positive effect on the employees' performance.

\section{Leadership Styles and Employee Performance}

As per leader-member exchange theory, leader's treatment to follower generates good relationship which results in a higher performance (Scott, Craven \& Green, 2006), stronger organisational commitment (Nystrom, 1990), and satisfaction (Ariani, 2012). Work force diversity and demographic changes are key factors which affect the performance (Saji, 2004). Transformational leaders not only align the individual goals with organisational goals but also help in promoting the followers skills and capabilities thus creating a sense of motivation among employees to think beyond the ordinary expectations. Leadership styles not only affect employee's job satisfaction and commitment but also improve productivity (Chen \& Silverthorne, 2005). The key factor for the organisation in this global era is its employees' satisfaction and the leaders having cordial relations with the followers. These factors promote innovative behaviour of employees, thus affecting their performance and further leading to business growth (Bushra, Ahmad \& Naveed, 2011). As such, we predict that leadership styles have positive relationship with the employees' performance. Following the above arguments, we propose the hypothesis.

$\mathrm{H}_{3}$ : Leadership style has a positive effect on the employees' performance.

\section{Organisational Commitment: A Mediator between Leadership Style and Employee Performance}

The organisational commitment and employee performance have a positive relationship (Somers \& Birnbaum, 1998). Low commitment results in the high turnover and the higher level of job satisfaction leads to the organisational commitment which, in turn, leads to the high level of employees' performance (Jackofsky, 1984). Transformational leadership has an edge on customary styles, especially in the achievement of the organisational outputs (Demirtas \& Akdogan, 2015), and inducing concentrated work efforts. Various studies have related leadership style to organisational commitment and employees' performance (Yahaya \& Ebrahim, 2016). According to Robins (2005), commitment with the organisation is achieved through trust on the 
management and it is only possible by adopting appropriate leadership styles. Social interaction among leaders and subordinates promotes higher levels of organisational commitment which leads to the achievement of organisational goals through employees' performance (Çelik, Dedeoğlu \& Inanir, 2015). As the combination of employee efforts and physical resources of organisations results in the products or services, in the same way, effective leadership helps in the organisational adaptation and transformation process (Babalola, 2016). Following the above arguments, we propose the hypothesis.

$\mathrm{H}_{4}$ : Organisational commitment mediates the relationship between leadership style and employees' performance.

The theoretical model we constructed is illustrated below. The model shows a strong connection between the leadership style, performance of the employees and organisational commitment. The model depicts that the leadership style impacts the organisational commitment and then, the organisational commitment leads the firm towards employees' performance. In other words, leadership styles impact the employees' performance indirectly through organisational commitment. Further, it also shows a direct relationship between the leadership styles and employees' performance as well.

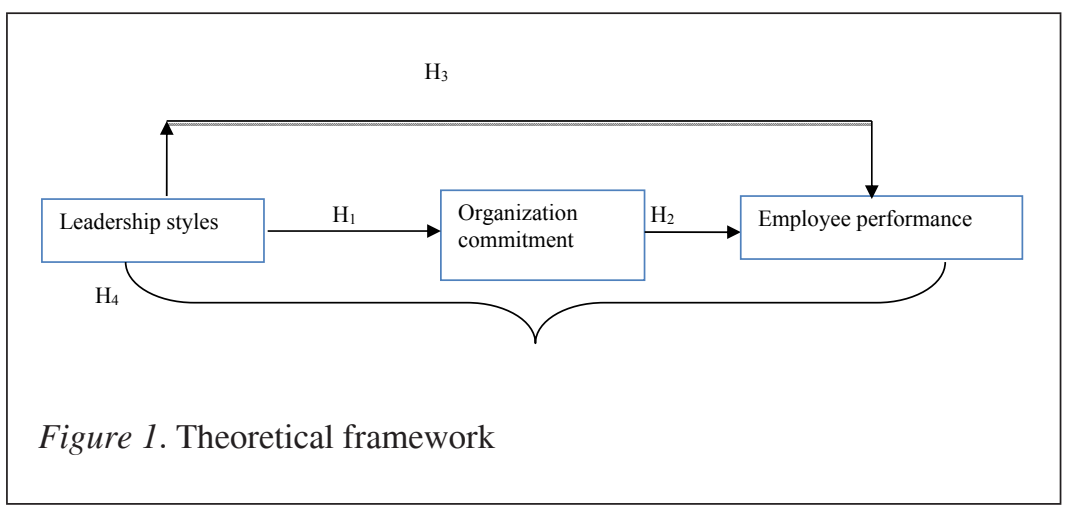

\section{Methodology}

\section{Data and Sample}

The study is basically quantitative in nature. The sample was taken using the questionnaire to examine the effect of leadership styles on the employees' performance. The questionnaire was sent to five manufacturing / service 
organisations based in Lahore, Pakistan. The participants were managers/ supervisors and employees. Approximately, 270 questionnaires were sent to these organisations but only 242 responses were returned with a response rate of 89 percent. These organisations were randomly selected. Any particular industry was not preferred because both leadership style and employee performance are not industry specific. The criteria for selection was that they had formally established the Human Resource Management and have at least 100 employees in place.

\section{Measures}

The dependent variable employee performance was measured by 10 items questions on a Likert scale of 1 (strongly agree) to 5 (strongly disagree) developed by Wright et al. (1995). The method used was more effective as it obtained the responses from participants than asking them directly to get the figures. Such measures are also used in SHRM research (Delaney \& Huselid, 1996). The independent variable transformational leadership style was measured through a multifactor leadership questionnaire method comprising 10 items questions on a Likert scale of 1 (Not at all) to 5 (Frequently if not always) developed by Avolio and Bass (2004). The mediating variable of the organisational commitment was measured based on six items (questions) on a Likert scale of 1 (strongly agree) to 5 (strongly disagree) developed by Meyer and Allen (1991).

\section{Analysis and Results}

We mailed and personally met with related persons to fill questionnaires from manufacturing and services industries in Lahore. 270 questionnaires were distributed and only 242 responses were received, with a response rate of 89 percent. In this research three variables were used; leadership styles, organisational commitment and employees' performance. The managers evaluated the employees' performance whilst the organisational commitment and leadership style were evaluated by the employees. Ten employees evaluated one manager/supervisor's leadership style and one supervisor evaluated ten employees' performance. The analysis was done using the descriptive statistics, regression analysis, correlation analysis and mediation analysis to obtain the results. Descriptive statistics were used to check the frequencies of gender, job nature, and experience. It was also used to check the mean and standard deviations of variables. Correlation was performed to check the relationships between variables. Regression was performed to check the impact of variables and to prove the hypothesis. To prove the mediator, the mediation analysis was performed. 
Table 1 shows the number of organisations selected and the number of samples from each sector.

Table 1

Sample of Sectors

\begin{tabular}{lll}
\hline Sectors & Number of companies & Sample \\
\hline Manufacturing & 11 & 159 \\
Services & 9 & 83 \\
\hline Total & 20 & 242 \\
\hline
\end{tabular}

Table 2 shows the frequencies of experience, job nature and the gender of the sample. Respondents with two years of experience responded the most. Among the four categories of job nature, 11.12 percent of respondents are office workers. Majority of respondents or 73.14 percent are males.

Table 2

Frequencies of Experience, Job Nature and Gender

\begin{tabular}{lclclc}
\hline \multicolumn{2}{c}{ Experience } & \multicolumn{3}{c}{ Job nature } & Gender \\
\hline Years & Frequency & & Frequency & Frequency \\
\hline 1 & 40 & Field work & 2 & Males & 177 \\
2 & 51 & Office work & 27 & Females & 65 \\
3 & 33 & Technical & 6 & & \\
4 & 12 & Managerial & 7 & & \\
5 & 26 & & & & \\
6 & 13 & & & & \\
7 & 20 & & & & \\
8 & 12 & & & & \\
9 & 11 & & & & \\
10 & 24 & & & & \\
\hline Total & 242 & Total & & & \\
\hline
\end{tabular}

Furthermore, Table 3 shows the results of mean, standard deviation and correlation analysis. The correlation results indicate that employer performance, organization commitment and the highest qualification have significant correlation with leadership style. Leadership style has the highest correlation with employer performance. 
Malaysian Management Journal Vol. 23, December 2019 115-134

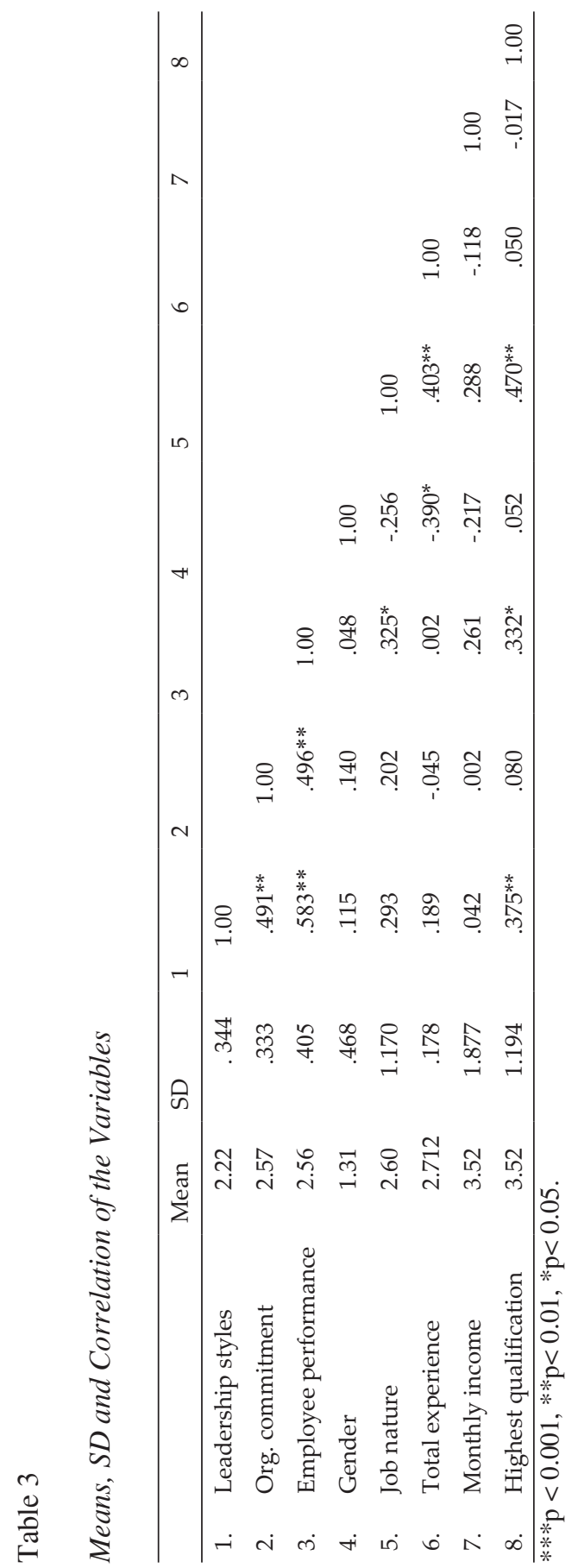


In Figure 2, the transformational leadership styles to organiaation commitment have a positive correlate, and the statistical value is significant $\left(\mathrm{R}^{2}=2.46\right.$, beta coefficient is $\left.0.476^{* *}, \mathrm{p}<0.001\right)$. On the other hand, the organisational commitment to employee performance has also a positive correlation and statistically significant $\left(\mathrm{R}^{2}=0.529\right.$, beta coefficient is $\left.0.602^{* * *}, \mathrm{p}<0.001\right)$. The relationship of leadership styles and employees performance has also a positive correlation, and the beta coefficient is significant $0.475^{* *}$. This supports our hypothesis that organisational commitment has a positive mediating role between the transformational leadership styles and the employee performance; the impact is insignificant (0.065).

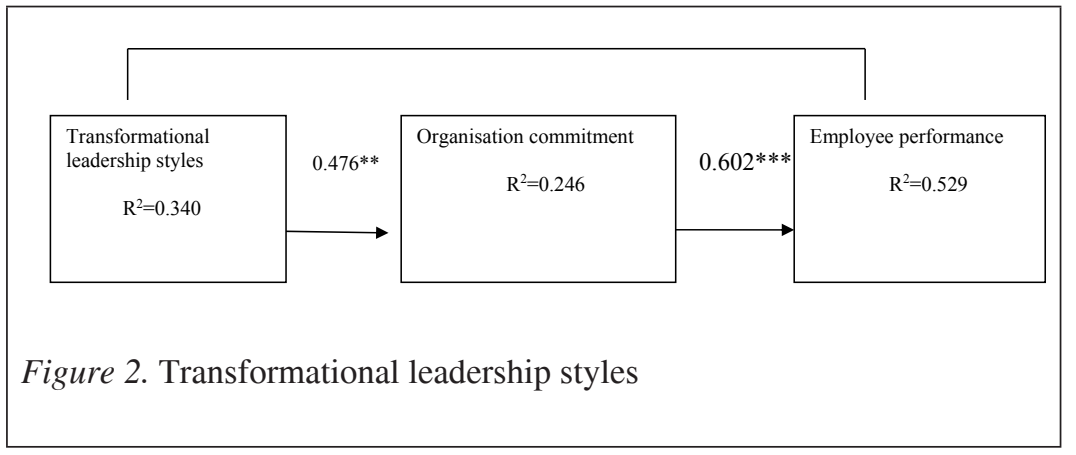

\section{Reliability Analysis}

Table 4 presents the Cronbach's alpha coefficient for variables of this research. Table 4 shows the Cronbach's alpha coefficient value for the leadership style which is 0.74 . Cronbach's alpha coefficient value for the employee performance is 0.71 . Cronbach's alpha coefficient value for the organisational commitment is 0.81 . Hair et al. (1998) suggested that the Cronbach's alpha value of 0.60 and above 1 is acceptable numeral for internal consistency.

Table 4

Modified Cronbach's Alpha

\begin{tabular}{lcc}
\hline Components & No. of items & Cronbach's Alpha \\
\hline Employees performance & 9 & 0.71 \\
Organizational commitment & 17 & 0.81 \\
Leadership style & 9 & 0.74 \\
\hline
\end{tabular}




\section{Regression Analysis}

This test was performed to check the impact and prove the hypothesis which showed the following results. Before performing regression analysis, the assumptions of regression analysis were checked according to the requirements. Shapiro-Wilk Normality test presented $p=0.377$ for leadership, $p=0.440$ for commitment and $p=0.106$ for employee performance, which proved normality. Firstly, the regression analysis was performed by taking leadership style as the independent variable and organisational commitment as the dependent variable. The results $\left(\beta=0.476, \mathrm{R}^{2}=0.340, p<0.001\right)$ indicate that the leadership style positively and significantly impacts the organisational commitment, proving our first hypothesis, that is, $\mathrm{H}_{1}$ : Leadership style has positive relationship with organisational commitment. Secondly, the regression analysis was performed using the organisational commitment as independent whereas the employee performance as the dependent variable. The results $\left(\beta=0.602, \mathrm{R}^{2}=0.246, p<0.001\right)$ show that organisational commitment positively and significantly impacts employee performance thus proving our second hypothesis that is, organisational commitment has positive effect on employee performance. Thirdly, we used leadership style as the independent variable while taking employee performance as the dependent variable and performed regression analysis. Results of the analysis $\left(\beta=0.475, \mathrm{R}^{2}=0.529 \mathrm{p}<0.001\right)$ present that the leadership style positively and significantly impacts employee performance thus proving our third hypothesis that is, leadership style has a positive effect on employee performance.

Then to check the fourth hypothesis which was based on mediation, we performed mediation analysis directly using SPSS. The result shows that employee performance that is enhanced through leadership styles and mediating role of organisational commitment is insignificance which proves that without organisational commitment, employee performance and leadership style has weak relationship (value is insignificance 0.65 which is more than 0.05 ). Thus, it proves our fourth hypothesis that organisational commitment mediates the relationship between leadership style and employee performance.

\section{Discussion and Future Research}

This study was conducted to examine the relationships between leadership style, organisational commitment and employee performance, and the demonstrated results supported our hypothesis. We found that appropriate leadership styles enhance the organisational commitment in the employees 
which, in turn, lead towards enhancing employee performance. Results also proved that organisational commitment is a good mediator which significantly mediates the relationships between leadership style and employee performance. Conceptually, it was confirmed that appropriate leadership style is very important in fostering organisational commitment among employees. Hence, this research proves that leadership style has an effect on employee performance only through certain organisational course such as organisational commitment.

The findings of our research showed consistent results across industries (controls having no significant coefficients) and therefore are generalisable. The findings of this empirical study have some implications for the organisations. Leaders in the organisations have to realise the importance of appropriate leadership style to enhance employees' performance which can give the organisation a competitive advantage. They also need to understand that only appropriate leadership can better manage human resource which will have appositive effect on the firm's performance.

As our research contributed to the literature of Human Resource Management (HRM), our findings should be interpreted carefully. Our study was done only in one city of Pakistan and having less time period. The sample size was also very small as compared to the requirements of study. Although sample size gave adequate results which can be generalised but a longitudinal study on the subject can yield better results.

Secondly, our study is relatively narrow in a sense that it highly focused on proving the relationships between variables and does not involve demographics information in the relationships testing so future researchers can involve demographic information and compare the results. Thirdly, we took only organizational commitment as the mediator, neglecting other attributes such as job satisfaction; future researchers can test it using the other attributes. Lastly there are some firm level factors such as organisational culture which might affect the relationships, thus, interested future researchers might test it by employing such moderator in the study.

\section{Conclusion}

To summarise, the current research aimed at proposing a mediation framework to elucidate leadership -performance relationship through the mediation of organisational commitment as a key factor for enhancing employees' performance. For practitioners, this research has revealed that simple relationship between leadership style and employee performance should not 
be assumed. Leadership style has to rely on organisational commitment to improve employee performance. Only leadership is not sufficed to bring forth the employee performance. To achieve competitive advantage, organisations need to develop a fit between leadership and performance.

\section{References}

Aarabi, M. S., Subramaniam, I. D., \& Akeel, A. B. A. A. B. (2013). Relationship between motivational factors and job performance of employees in Malaysian service industry. Asian Social Science, 9(9), 301.

Akerlof, G. A., \& Kranton, R. (2010). Identity economics. The Economists' Voice, 7(2), 715-753.

Alkahtani, A. H. (2015). The influence of leadership styles on organizational commitment: The moderating effect of emotional intelligence. Business and Management Studies, 2(1), 23-34.

Alonso, P., \& Lewis, G. B. (2001). Public service motivation and job performance: Evidence from the federal sector. The American Review of Public Administration, 31(4), 363-380.

Ardichvili, A., \& Manderscheid, S. V. (2008). Emerging practices in leadership development: An introduction. Los Angeles: Sage.

Ariani, D. W. (2012). Leader-member exchanges as a mediator of the effect of job satisfaction on affective organizational commitment: An empirical test. International Journal of Management, 29(1), 46.

Arnold, K. A., Barling, J., \& Kevin Kelloway, E. (2001). Transformational leadership or the iron cage: which predicts trust, commitment and team efficacy? Leadership \& Organization Development Journal, 22(7), 315-320.

Avolio, B. J., \& Bass, B. M. (2004). Multifactor leadership questionnaire (MLQ). Mind Garden, 29.

Babalola, S. S. (2016). The effect of leadership style, job satisfaction and employee-supervisor relationship on job performance and organizational commitment. Journal of Applied Business Research, 32(3), 935.

Bass, B. M. (1985). Leadership and performance beyond expectations: New Jersey: Collier Macmillan.

Bass, B. M., \& Stogdill, R. M. (1990). Bass \& Stogdill's handbook of leadership: Theory, research, and managerial applications: New Jersey: Simon and Schuster.

Brown, D., \& Sargeant, M. A. (2007). Job satisfaction, organizational commitment, and religious commitment of full-time university employees. Journal of Research on Christian Education, 16(2), 211241. 
Buchanan, B. (1974). Building organizational commitment: The socialization of managers in work organizations. Administrative science quarterly, 533-546.

Buelens, M., \& Van den Broeck, H. (2007). An analysis of differences in work motivation between public and private sector organizations. Public Administration Review, 67(1), 65-74.

Bushra, F., Ahmad, U., \& Naveed, A. (2011). Effect of transformational leadership on employees' job satisfaction and organizational commitment in banking sector of Lahore (Pakistan). International Journal of Business and Social science, 2(18).

Çelik, S., Dedeoğlu, B. B., \& Inanir, A. (2015). Relationship between ethical leadership, organizational commitment and job satisfaction at hotel organizations. Ege Academic Review, 15(1).

Chaudhary, N., \& Sharma, B. (2012). Impact of employee motivation on performance (productivity) in private organization. International Journal of Business Trends and Technology, 2(4), 29-35.

Chen, J.-C., \& Silverthorne, C. (2005). Leadership effectiveness, leadership style and employee readiness. Leadership \& Organization Development Journal, 26(4), 280-288.

Choi, S. B., Kim, K., Ullah, S. E., \& Kang, S.-W. (2016). How transformational leadership facilitates innovative behavior of Korean workers: Examining mediating and moderating processes. Personnel Review, 45(3), 459-479.

Delaney, J. T., \& Huselid, M. A. (1996). The impact of human resource management practices on perceptions of organizational performance. Academy of management Journal, 39(4), 949-969.

Demirtas, O., \& Akdogan, A. A. (2015). The effect of ethical leadership behavior on ethical climate, turnover intention, and affective commitment. Journal of Business Ethics, 130(1), 59-67.

Den Hartog, D. N., \& Verburg, R. M. (1997). Charisma and rhetoric: Communicative techniques of international business leaders. The Leadership Quarterly, 8(4), 355-391.

Dessler, G. (1999). How to earn your employees' commitment. Academy of Management Perspectives, 13(2), 58-67.

Dong, Y., Bartol, K. M., Zhang, Z. X., \& Li, C. (2017). Enhancing employee creativity via individual skill development and team knowledge sharing: Influences of dual focused transformational leadership. Journal of Organizational Behavior, 38(3), 439-458.

DuBrin, J. A. (1998). Leadership research findings practical and skill. New York:Houghton Miffin.

Dvir, T., Eden, D., Avolio, B. J., \& Shamir, B. (2002). Impact of transformational leadership on follower development and performance: A field experiment. Academy of management Journal, 45(4), 735-744. 
Erkutlu, H. (2008). The impact of transformational leadership on organizational and leadership effectiveness: The Turkish case. Journal of Management Development, 27(7), 708-726.

Farndale, E., Van Ruiten, J., Kelliher, C., \& Hope Hailey, V. (2011). The influence of perceived employee voice on organizational commitment: An exchange perspective. Human Resource Management, 50(1), 113129.

Germain, M. L. (2012). Traits and skills theories as the nexus between leadership and expertise: Reality or fallacy? Performance Improvement, 51(5), 3239.

Ghasabeh, M. S., Soosay, C., \& Reaiche, C. (2015). The emerging role of transformational leadership. The Journal of Developing Areas, 49(6), 459-467.

Grant, A. M. (2012). Leading with meaning: Beneficiary contact, prosocial impact, and the performance effects of transformational leadership. Academy of Management Journal, 55(2), 458-476.

Halbesleben, J. R., \& Bowler, W. (2007). Emotional exhaustion and job performance: the mediating role of motivation. Journal of Applied Psychology, 92(1), 93.

Hayward, Q., Goss, M., \& Tolmay, R. (2004). The relationship between transformational and transactional leadership and employee commitment. Grahamstown: Rhodes University, Business Report.

House, R. J., \& Mitchell, T. R. (1975). Path-goal theory ofleadership. Washington University Seattle Dept of Psychology.

Jackofsky, E. F. (1984). Turnover and job performance: An integrated process model. Academy of Management Review, 9(1), 74-83.

Jamaludin,Z., Rahman, N., Makhbul,Z. K. M., \& Idris, F. (2011). Do transactional, transformational and spiritual leadership styles distinct? A conceptual insight. Journal of Global Business and Economics, 2(1), 73-85.

Kanter, R. M. (1968). Commitment and social organization: A study of commitment mechanisms in utopian communities. American Sociological Review, 499-517.

Khan, D. (2016). Leadership style and organization performance. Retrieved from https://mpra.ub.uni-muenchen.de/70387/

Khan, R. A. G., Khan, F. A., \& Khan, M. A. (2011). Impact of training and development on organizational performance. Global Journal of Management and Business Research, 11(7).

Kofman, F., \& Senge, P. M. (1993). Communities of commitment: The heart of learning organizations. Organizational dynamics, 22(2), 5-23.

Lee, P., Gillespie, N., Mann, L., \& Wearing, A. (2010). Leadership and trust: Their effect on knowledge sharing and team performance. Management learning, 41(4), 473-491.

Lo, M.-C., Ramayah, T., Min, H. W., \& Songan, P. (2010). The relationship between leadership styles and organizational commitment in 
Malaysia: role of leader-member exchange. Asia Pacific Business Review, 16(1-2), 79-103.

Manz, C. C., \& Sims Jr, H. P. (1991). Superleadership: Beyond the myth of heroic leadership. Organizational Dynamics, 19(4), 18-35.

Masa'deh, R. e., Obeidat, B. Y., \& Tarhini, A. (2016). A Jordanian empirical study of the associations among transformational leadership, transactional leadership, knowledge sharing, job performance, and firm performance: A structural equation modelling approach. Journal of Management Development, 35(5), 681-705.

McCleskey, J. A. (2014). Situational, transformational, and transactional leadership and leadership development. Journal of Business Studies Quarterly, 5(4), 117.

Meyer, J. P., \& Allen, N. J. (1991). A three-component conceptualization of organizational commitment. Human Resource Management Review, 1(1), 61-89.

Miller, E. K., \& Cohen, J. D. (2001). An integrative theory of prefrontal cortex function. Annual Review of Neuroscience, 24(1), 167-202.

Morden, T. (1997). Leadership as vision. Management Decision, 35(9), 668676.

Newman, D. A., \& Harrison, D. A. (2008). Been there, bottled that: Are state and behavioral work engagement new and useful construct "wines"? Industrial and Organizational Psychology, 1(1), 31-35.

$\mathrm{Ng}, \mathrm{T}$. W. (2015). The incremental validity of organizational commitment, organizational trust, and organizational identification. Journal of Vocational Behavior, 88, 154-163.

Nijhof, W. J., de Jong, M. J., \& Beukhof, G. (1998). Employee commitment in changing organizations: an exploration. Journal of European Industrial Training, 22(6), 243-248.

Nystrom, P. C. (1990). Vertical exchanges and organizational commitments of American business managers. Group \& Organization Studies, 15(3), 296-312.

Porter, L. W., \& Lawler, E. E. (1968). What job attitudes tell about motivation. Harvard Business Review, 46(1), 118-126.

Pradhan, S., \& Pradhan, R. K. (2015). An empirical investigation of relationship among transformational leadership, affective organizational commitment and contextual performance. Vision, 19(3), 227-235.

Prasetya, A., \& Kato, M. (2011). Employees' perception towards the performance assessment system and salary system. Paper presented at the Proceeding from ICETD (International Conference on Economics, Trade, and Development)-Bali Island.

Randall, D. M., Fedor, D. B., \& Longenecker, C. O. (1990). The behavioral expression of organizational commitment. Journal of Vocational Behavior, 36(2), 210-224. 
Robbins, S. P., \& Coulter, M. (2007). Principles of management. Translated by Seyyed Mohammad Arabi and Mohammed Ali Hamid Rafiee and Behrouz Asrari Ershad, Fourth Edition, Tehran: Office of Cultural Studies.

Sabir, M. S., Sohail, A., \& Khan, M. A. (2011). Impact of leadership style on organization commitment: In a mediating role of employee values. Journal of Economics and Behavioral Studies, 3(2), 145-152.

Saji, B. S. (2004). Workforce diversity, temporal dimensions and team performance. Cross Cultural Management: An International Journal, 11(4), 40-59.

Sarros, J. C., \& Woodman, D. S. (1993). Leadership in Australia and its organizational outcomes. Leadership \& Organization Development Journal, 14(4), 3-9.

Schaubroeck, J., Lam, S. S., \& Cha, S. E. (2007). Embracing transformational leadership: Team values and the impact of leader behavior on team performance. Journal of Applied Psychology, 92(4), 10-20.

Scott, J., Craven, A. E., \& Green, C. (2006). A meta-analysis of organizational citizenship behavior and leader-member exchange. Journal of Business \& Economics Research, 4(11).

Sergiovanni, T., \& Corbally, J. (1984). Leadership and organizational culture. Urbana, IL: University of Illinois Press.

Shah, S. M. M., Majid, A. H. B. A., Samo, A. H., \& Memon, P. A. (2016). The relationship between transformational leadership and job performance: An empirical investigation. Sukkur IBA Journal of Management and Business, 3(2), 25-38.

Smith, P. B., \& Peterson, M. F. (1988). Leadership, organizations and culture: An event management model. New Jersey: Sage Publications.

Somers, M. J., \& Birnbaum, D. (1998). Work related commitment and job performance: It's also the nature of the performance that counts. Journal of Organizational Behavior: The International Journal of Industrial, Occupational and Organizational Psychology and Behavior, 19(6), 621-634.

Vigoda-Gadot, E. (2007). Leadership style, organizational politics, and employees' performance: An empirical examination of two competing models. Personnel Review, 36(5), 661-683.

Wright, B. E., Moynihan, D. P., \& Pandey, S. K. (2012). Pulling the levers: Transformational leadership, public service motivation, and mission valence. Public Administration Review, 72(2), 206-215.

Yahaya, R., \& Ebrahim, F. (2016). Leadership styles and organizational commitment: literature review. Journal of Management Development, 35(2), 190-216.

Yukl, G. A., \& Yukl, G. (2002). Leadership in organizations. Upper Saddle River: Prentice Hall. 